\title{
Jurist-Diction
}

Volume 4 No. 5 September 202

\section{Peranan Badan Pengawas Obat dan Makanan dalam Perlindungan Konsumen Terhadap Obat Racikan Apotek Tanpa Resep Dokter}

\author{
Zsalzsabella Putri Moudzie \\ chacamoudzie@gmail.com \\ Universitas Airlangga
}

How to cite:

Zsalzsabella Putri Moudzie 'Peranan Badan Pengawas Obat dan Makanan dalam Perlindungan Konsumen Terhadap Obat Racikan Apotek Tanpa Resep Dokter' (2021) Vol. 4 No. 5 Jurist-Diction.

\section{Histori artikel:}

Submit 9 Juli 2021;

Diterima 15 Agustus 2021;

Diterbitkan 1 September 2021.

DOI:

10.20473/jd.v4i5.29835

p-ISSN: 2721-8392

e-ISSN: $2655-8297$

\section{Abstract}

The rise of pharmaceutical business actors, in this case, is a pharmacy, in selling concoction drugs without a doctor's prescription in several regions in Indonesia causing losses in consumers. Consumer protection is regulated in Act Number 8 of 1999 concerning Consumer Protection, then consumer rights in the health sector are recognized by Act Number 36 of 2009 concerning Health. Both of these regulations require that at least the consumer is guaranteed his right to use the drug, including comprehensive information related to the drug obtained at the Pharmacy. This is not heeded by a number of pharmacies in Indonesia who pack concoction drugs in plastic packages and do not meet the information standards that must be listed. BPOM as an institution that is given authority in law enforcement for drug distribution that is not in accordance with standards can take product withdrawal as well as administrative sanctions against business actors. In addition, the Consumer Protection Act provides a platform for consumers who are disadvantaged to be able to file liability through the Consumer Dispute Resolution Agency (BPSK).

Keywords: BPOM; BPSK; Compounding Drugs; Consumer Protection.

\begin{abstract}
Abstrak
Maraknya pelaku kegiatan usaha kefarmasian, dalam hal ini adalah apotek, dalam menjual obat racikan tanpa resep dokter di beberapa daerah di Indonesia menimbulkan kerugian-kerugian dalam diri konsumen. Perlindungan konsumen diatur dalam Undang-Undang Nomor 8 Tahun 1999 tentang Perlindungan Konsumen, kemudian mengenai hak konsumen dalam bidang kesehatan diakui oleh UndangUndang Nomor 36 Tahun 2009 tentang Kesehatan. Kedua peraturan tersebut mengharuskan setidaknya konsumen terjamin hak nya dalam penggunaan obat, termasuk pula informasi lengkap terkait obat yang didapatkan di Apotek. Hal ini tidak diindahkan oleh beberapa apotek di Indonesia yang mengemas obat racikan dalam kemasan plastik dan tidak memenuhi standar informasi yang harus dicantumkan. BPOM sebagai lembaga yang diberi kewenangan dalam penegakan hukum terhadap peredaran obat yang tidak sesuai dengan standar dapat melakukan tindakan penarikan produk serta sanksi administratif kepada pelaku usaha. Selain itu, UU Perlindungan Konsumen memberikan wadah bagi konsumen yang dirugikan untuk dapat mengajukan pertanggung gugatan melalui Badan Penyelesaian Sengketa Konsumen (BPSK).

Kata Kunci: BPOM; BPSK; Obat Racikan; Perlindungan Konsumen.

Copyright (C) 2021 Zsalzsabella Putri Moudzie
\end{abstract}




\section{Pendahuluan}

Adanya perdagangan bebas dan teknologi yang semakin canggih, tentunya memudahkan manusia untuk saling berkomunikasi dan melebarkan ruang lingkup kegiatan usahanya. Dalam kegiatan usaha, dikenal pula istilah konsumen dan pelaku usaha. Hubungan antara konsumen dan pelaku usaha mempunyai kewajiban dan hak dari masing-masing pihak yang telah diatur dalam Undang-Undang. Lemahnya kedudukan konsumen membuat para pelaku usaha meraup keuntungan yang lebih besar. Sehingga sering kali konsumen dirugikan atas tindakan seperti itu. Hal ini mendorong pemerintah untuk mengesahkan Undang-Undang Nomor 8 Tahun 1999 tentang Perlindungan Konsumen atau biasa disingkat menjadi UUPK. Undang-Undang ini berlaku setelah setahun sejak disahkan, tepatnya pada tanggal 20 April $2000 .{ }^{1}$

Perlindungan konsumen ini berlaku pula bagi konsumen layanan kesehatan. Salah satu konsumen layanan kesehatan dikenal dengan istilah konsumen obatobatan. Konsumen obat sendiri adalah seseorang yang mengkonsumsi obat untuk menyembuhkan penyakitnya. Konsumen obat ini biasanya bergantung pada dokter yang akan memberikan informasi terkait penatalaksanaan obat, termasuk jenis obat yang akan dikonsumsi. Di Indonesia, penyedia layanan farmasi salah satunya dilakukan oleh Apotek. Menurut UU Nomor 51 Tahun 2009 tentang Pekerjaan Kefarmasian, apoteker adalah seseorang yang memiliki keahlian dan kewenangan di bidang kefarmasian dan telah mengucapkan sumpah jabatan apoteker. Sehingga, segala kegiatan apoteker dalam memberikan obat dan melayani kebutuhan masyarakat dalam hal kesehatan harus sesuai dengan apa yang disumpahkan dalam sumpah jabatannya.

Peracikan menjadi perhatian oleh karena banyak munculnya kejadian yang tidak dikehendaki meliputi kesalahan pengobatan, kualitas racikan, serta masalah kontaminasi bakteri. Obat racikan adalah obat yang dibentuk dengan mengubah atau mencampur sediaan obat atau bahan aktif. Bentuk obat racikan bisa berupa

\footnotetext{
${ }^{1}$ Gunawan Widjaja dan Ahmad Yani, Hukum Tentang Perlindungan Konsumen (Gramedia Pustaka Utama 2000).[6].
} 
bentuk padat, semi padat maupun cair. ${ }^{2}$ Sebagaimana yang telah diketahui bahwa obat adalah suatu produk kesehatan yang dalam penggunaannya harus mengikuti tata cara dan berbagai macam persyaratan. ${ }^{3}$ Dalam penggunaannya, obat yang dikonsumsi harus telah memiliki izin edar dan apabila menggunakan obat keras harus berdasarkan dengan resep dokter.

Badan Pengawas Obat dan Makanan selanjutnya disingkat menjadi BPOM diberikan kewenangan sebagai badan yang berwenang memberikan perlindungan kepada masyarakat atas peredaran obat. Permasalahan yang kini dihadapi dan berkembang di masyarakat adalah maraknya apotek (apoteker sebagai subyeknya) meracik obat-obatan dan dikemas sendiri menggunakan kemasan rumahan (plastik) atau bahkan hanya dibungkus koran dengan tanpa mencantumkan informasi terkait. Hal ini tentu sangat menyimpang dengan Peraturan BPOM Nomor 4 Tahun 2018 Pasal 7 bahwa "Tenaga kefarmasian dalam melakukan pengelolaan obat, bahan obat, narkotika, psikotropika dan prekursor farmasi di fasiitas pelayanan kefarmasian harus sesuai dengan standar pelayanan kefarmasian". Sedangkan disisi lain konsumen juga berhak untuk mendapatkan informasi yang benar, jelas, dan jujur mengenai kondisi dan jaminan atas barang yang didapatnya sesuai yang tercantum didalam Undang-Undang Nomor 8 Tahun 1999 Tentang Perlindungan Konsumen Pasal 4 ayat (3).

Dalam kegiatannya, obat racikan dari apotek tersebut diedarkan ke toko obat, pasar, toko kelontong, dsb. Seperti contoh hal nya yang terjadi di Surabaya terdapat apotek yang menjual obat yang diracik dengan tanpa menggunakan resep dokter. Tentunya obat racikan yang dijual di apotek itu dijual secara diam-diam dengan tanpa memberikan informasi terkait komposisi, efek samping, tanggal kadaluwarsa, diberikan langsung dengan tanpa resep dokter dan tidak memiliki izin edar. Sehingga, konsumen tidak akan tahu apakah ia mempunyai alergi atau semacamnya dengan

\footnotetext{
${ }^{2}$ Ria Widyaswari, Chairun Wiedyaningsih, 'Evaluasi Profil Peresepan Obat Racikan Dan Ketersediaan Formula Obat Untuk Anak Di Puskesmas Propinsi DIY', (Majalah Farmasuetik 2012) 8(3).[228]. <https://jurnal.ugm.ac.id/majalahfarmaseutik/article/view/24079/15756> accessed on 12 Januari 2020.

${ }^{3}$ H.A. Syamsuni, Ilmu Resep (EGC 2007).[143].
} 
bahan yang ada pada obat tersebut. Karena hal tersebut bisa sangat membahayakan konsumen apabila menimbulkan efek samping yang tidak diinginkan.

Meskipun harga yang diberikan sangat murah, tetapi hal tersebut tidak boleh mempengaruhi keterangan informasi yang seharusnya diberikan kepada konsumen. Dan seharusnya, pihak apoteker juga tidak memberikan obat yang tidak ada izin edar nya untuk dikonsumsi oleh konsumen. Label informasi yang ada pada obat memang sangat penting untuk dicantumkan. Latar belakang dari dicantumkannya label informasi pada obat sebenarnya karena masyarakat yang masih awam terhadap informasi obat, cara pemakaian, efek samping pada obat. Sehingga apabila hal tersebut tidak dilaksanakan oleh pihak produsen obat maka dapat dikatakan bahwa konsumen tidak mendapatkan haknya atas obat yang didapat.

Terjadinya transaksi jual-beli obat racikan tanpa resep dokter tersebut dapat menimbulkan "masalah" antara pelaku usaha dan konsumen, karena dalam hal ini obat racikan itu tidak tertera pengaturan komposisi, label, dan yang terpenting adalah ijin edar.

\section{Legalitas Obat Racikan Apotek Tanpa Resep Dokter}

Di Indonesia, seluruh obat yang akan di edarkan sebelumnya harus dilakukan registrasi untuk memperoleh izin edar. Izin edar ini diberikan oleh menteri yang kemudian dilimpahkan pemberian izin edar kepada Kepala Badan. Disamping itu, dijelaskan pula dalam Pasal 2 ayat (4) Peraturan Menteri Kesehatan Republik Indonesia Nomor 1010/MENKES/PER/XI/2008 Tentang Registrasi Obat terdapat pengecualian terhadap :

a. Obat penggunaan khusus atas permintaan dokter;

b. Obat Donasi;

c. Obat untuk Uji Klinik;

d. Obat Sampel untuk registrasi.

Obat-obat tersebut dapat dimasukkan ke wilayah Indonesia melalui mekanisme jalur khusus yang telah ditetapkan oleh Menteri. Jika dilihat dalam aturan Undang-Undang Nomor 36 Tahun 2009 tentang Kesehatan (UU Kesehatan), obat merupakan bahan atau paduan bahan, termasuk produk biologi yang digunakan 
untuk mempengaruhi atau menyelidiki sistem fisiologi atau keadaan patologi dalam rangka penetapan diagnosis, pencegahan, penyembuhan, pemulihan, peningkatan kesehatan dan kontrasepsi, untuk manusia. ${ }^{4}$ Sehingga dalam sediaan farmasi tersebut harus aman, berkhasiat/bermanfaat, bermutu, dan terjangkau. Dengan demikian obat hanya dapat di edarkan setelah mendapat izin edar.

Dalam pengaturan penetapan izin edar ini juga bertujuan untuk melindungi masyarakat dari bahaya yang disebabkan oleh penggunaan obat yang tidak memenuhi standar, persyaratan mutu, keamanan, khasiat/manfaat dan gizi dalam kandungan obat tersebut. Sehingga disini pemerintah berwenang untuk mengatur standar dan persyaratan keamanan, mutu, dan khasiat/manfaat yang terkandung dalam suatu obat. Pemerintah berperan melindungi masyarakat melalui pengawasan pre-market dan post-market. Pengawasan pre-market ini dilakukan melalui upaya pemberian izin edar. Hanya produk obat dan makanan yang telah memiliki izin edar yang diperbolehkan untuk diedarkan di masyarakat. Disisi lain, pengawasan post-market dilakukan melalui upaya pengawasan rutin dan pengujian sampel produk yang telah beredar di masyarakat. ${ }^{5}$

Begitu pentingnya izin edar ini dapat dilihat dari sulit dan ketatnya pemberian izin edar oleh Badan Pengawas Obat dan Makanan. Sehingga patut diduga bahwa obat yang tidak mempunyai izin edar memiliki bahan-bahan yang berbahaya, tidak jelas produsennya dan tidak menjamin keselamatan konsumen. ${ }^{6}$ Apabila terdapat obat yang tidak memiliki izin edar dan diperdagangkan secara luas, maka pihak yang dirugikan tentunya adalah konsumen. Dan hal tersebut akan sulit untuk dipertanggungjawabkan jika obat yang dikonsumsi mengandung bahan-bahan yang berbahaya.

Berdasarkan Peraturan Menteri Kesehatan Nomor 73 Tahun 2016 Tentang Standar Pelayanan Kefarmasian di Apotek, peracikan merupakan bagian dari

\footnotetext{
${ }^{4}$ Ps. 1 angka 8 Undang-Undang No. 36/2009.

${ }^{5}$ Rahmi Yuningsih, 'Penguatan Kendali Pemerintah Terhadap Peredaran Obat dan Makanan' (2017) 8 Jurnal Aspirasi.[14].

${ }^{6}$ Muhammad Alfan Nur Zuhaid, Bambang Eko Turisno, dan R.Suharto, 'Perlindungan Konsumen Terhadap Peredaran Obat Tanpa Izin Edar yang Dijual Secara Online di Indonesia', (2016) 5(3) Diponegoro Law Journal.[5].
} 
dispensing yang hanya dilakukan apabila diperlukan. Hal ini merupakan bagian dari pelayanan farmasi klinik di apotek yang disebutkan pada Pasal 3 ayat (3) Permenkes tersebut, yaitu:

a. Pengkajian Resep;

b. Dispensing;

c. Pelayanan Informasi Obat (PIO);

d. Konseling;

e. Pelayanan Kefarmasian di rumah (home pharmacy care);

f. Pemantauan Terapi Obat (PTO);

g. Monitoring Efek Samping Obat (MESO).

Kemudian pada Bab III Lampiran Permenkes tersebut mengatur lebih lanjut mengenai Pelayanan Farmasi Klinik. Pada huruf B dijelaskan mengenai dispensing yang menyebutkan sesaat setelah melakukan pengkajian resep, dilakukan:

1. Menyiapkan obat sesuai dengan permintaan resep:

a. Menghitung kebutuhan jumlah obat sesuai dengan resep;

b. Mengambil obat yang dibutuhkan pada rak penyimpanan dengan memperhatikan nama obat, tanggal kadaluwarsa dan keadaan fisik obat.

2. Melakukan peracikan obat bila diperlukan

3. Memberikan etiket sekurang-kurangnya:

a. Warna putih untuk obat dalam/oral;

b. Warna biru untuk obat luar dan suntik;

c. Menempelkan label "kocok dahulu" pada sediaan bentuk suspensi atau emulsi.

4. Memasukkan obat ke dalam wadah yang tepat dan terpisah untuk obat yang berbeda untuk menjaga mutu obat dan menghindari penggunaan yang salah.

Permenkes tersebut telah secara jelas menjabarkan proses pelaksanaan farmasi klinik oleh apotek, dengan secara khusus menyebutkan peracikan obat dilakukan apabila diperlukan.

Resep merupakan perwujudan akhir dari kompetisi, pengetahuan dan keahlian dokter dalam menerapkan pengetahuannya di bidang farmakologi dan terapi. Resep ini juga sebagai bentuk perwujudan hubungan antara dokter, apoteker, dan pasien. Penulisan resep harus ditulis dengan jelas sehingga nantinya dapat dibaca oleh petugas di Apotek. Resep yang ditulis dengan tidak jelas memungkinkan timbulnya kesalahan saat peracikan/penyiapan obat dan penggunaan obat yang diresepkan. ${ }^{7}$

\footnotetext{
${ }^{7}$ Rahmatini, 'Agar Penulisan Resep Tetap Up To Date' (2009) 33(2) Majalah kedokteran Andalas.[103].
} 
Dalam kaitan resep dengan penyerahan obat oleh apotek, dari penjelasan Bab III Lampiran Permenkes No. 73 Tahun 2016 tentang Standar Pelayanan Kefarmasian di Apotek tergambar bahwa obat yang dikehendaki dapat berupa obat jadi ataupun obat yang harus melalui compounding atau peracikan terlebih dahulu. Apotek yang telibat dalam peracikan harus memiliki area yang dipilih secara khusus dengan ruang yang memadai untuk penempatan peralatan dan bahan yang digunakan. Apoteker juga bertanggung jawab atas perawatan yang tepat, kebersihan, dan penggunaan semua peralatan dalam praktek peracikan tersebut. ${ }^{8}$

Penyerahan sediaan farmasi maupun alat kesehatan dilakukan dengan tujuan untuk digunakan dalam pelayanan kesehatan dalam rangka pemeliharaan dan peningkatan derajat kesehatan masyarakat, atau kepentingan ilmu pengetahuan yang bertujuan untuk penelitian dan pengembangan sediaan farmasi yang akhirnya hasilnya dapat digunakan untuk pelayanan kesehatan. Dalam penyerahan sediaan farmasi yang digunakan dalam pelayanan kesehatan dilakukan berdasarkan: ${ }^{9}$
a. Resep Dokter;
b. Tanpa Resep Dokter.

Sebagaimana yang telah diatur di dalam PP Farmasi bahwa Apoteker hanya dapat menyerahkan obat keras, narkotika, dan psikotropika kepada masyarakat atas resep dari dokter sesuai dengan ketentuan peraturan perundang-undangan (Pasal 24 Huruf C PP Farmasi No 51 Tahun 2009). Hal ini juga dapat dilihat dari Keputusan Menteri Kesehatan Republik Indonesia Nomor 02396/A/SK/VIII/1986 Tahun 1986 Tentang Tanda Khusus Obat Keras Daftar G (Kepmenkes 2396/1986). Peraturan ini menyebutkan bahwa obat keras hanya dapat diberikan dengan resep dokter, yaitu dalam Pasal 2 Kepmenkes 2396/1986:

1. Pada etiket dan bungkus luar obat jadi yang tergolong obat keras harus dicantumkan secara jelas tanda khusus untuk obat keras;

\footnotetext{
${ }^{8}$ Loyd V. Allen, 'The Art, Science, and Technology of Pharmaceutical Compounding: Fifth Edition', (International Journal of Pharmaceutical Compounding).[6]. <https://www.pharmacist. $\mathrm{com} / \mathrm{sites} / \mathrm{default} /$ files/files/Allen_\%20Chap_\%201_Art\%2C\%20Science\%20and\%20Technology\%20of\%20Pharmaceutical\%20Compounding\%2C\%204e.pdf $>$ accessed on 12 Januari 2020.

${ }^{9}$ Lihat Ps. 16 PP No. 72/1998.
} 
2. Ketentuan dimaksud dalam ayat (1) merupakan pelengkap dari keharusan mencantumkan kalimat "Harus dengan resep dokter" yang ditetapkan dalam Keputusan Menteri Kesehatan Nomor 197/A/SK/77 tanggal 15 Maret 1977;

3. Tanda khusus dapat tidak dicantumkan pada blister, strip, aluminium/selofan, vial, ampul, tube, atau bentuk wadah lain, apabila wadah tersebut dikemas dalam bungkus luar.

Sehingga pada dasarnya untuk dapat membeli obat keras, dibutuhkan resep dari dokter. Perlu diketahui bahwa tidak hanya obat keras yang memerlukan resep dari dokter. Prekursor Farmasi obat keras juga hanya dapat diberikan atas resepp dokter. ${ }^{10}$ Seperti yang telah diatur dalam Peraturan Menteri Kesehatan Republik Indonesia Nomor 3 Tahun 2015 Tentang Peredaran, Penyimpanan, Pemusnahan Dan Pelaporan Narkotika, Psikotropika, Dan Prekursor Farmasi ( Permenkes 3/2015). Prekursor Farmasi merupakan zat atau bahan pemula atau bahan kimia yang dapat digunakan sebagai bahan baku/penolong untuk keperluan proses produksi industri farmasi atau produk antara, produk rumahan, dan produk jadi yang mengandung ephedrine, pseudoephedrine, norephedrine atau phenylpropanolamine, ergotamin, ergometrine, atau Potasium Permanganat (Pasal 1 angka 3 Permenkes 3/2015). Apotek, Puskesmas, Instalasi Farmasi Rumah Sakit, dan Instalasi Farmasi Klinik hanya dapat menyerahkan Prekursor Farmasi golongan obat keras kepada pasien berdasarkan resep dokter. (Pasal 22 ayat (3) Permenkes No.3 Tahun 2015).

\section{Kewenangan BPOM dan Tanggung Gugat Atas Pelanggaran Obat Racikan Apotek Tanpa Resep Dokter}

Badan Pengawas Obat dan Makanan (BPOM) merupakan lembaga negara non-departemen. BPOM memiliki koordinasi yang sangat erat dengan Dinas Kesehatan karena awal mula berdirinya BPOM berasal dari Departemen Kesehatan

\footnotetext{
${ }^{10}$ Beni Satria, “Apotek Dan Apoteker Menjual Obat Tanpa Resep Dokter, Bagaimana Hukumnya?” (www.best-dokter.com 2017), accessed on 14 Januari 2020.
} 
(yang sekarang berubah menjadi Dinas Kesehatan). ${ }^{11}$ Pelaksanaan tugas BPOM dikoordinasikan oleh Menteri Kesehatan dan bertujuan untuk melaksanakan tugas pemerintah dibidang pengawasan obat dan makanan dan BPOM bertanggung jawab langsung kepada presiden.

Pelaksanaan pengawasan yang dilakukan oleh BPOM sejatinya harus dilaksanakan sejalan dengan ketentuan atau kebijakan yang juga dilakukan oleh Departemen Kesehatan, dimaksudkan untuk meningkatkan kualitas pengawasan terhadap obat dan makanan yang sebenarnya saling berkaitan agar masyarakat dapat memperoleh kualitas obat dan makanan yang telah memenuhi standar dan persyaratan kesehatan. BPOM tidak bisa terlepas dari koordinasi dengan departemen kesehatan meskipun secara struktural tidak mempunyai ikatan. BPOM merupakan lembaga atau badan yang melakukan fungsi regulasi sebagai wujud perwakilan dari pemerintah. Fungsi dari pemerintahan ini dapat ditentukan sedikit banyak dengan menempatkannya dalam hubungan dengan fungsi perundang-undangan. ${ }^{12}$

Tugas dan kewenangan BPOM terdapat pada Peraturan Presiden Nomor 80 Tahun 2017 dalam Pasal 4 tentang Badan Pengawas Obat dan Makanan yang menyatakan bahwa BPOM mempunyai kewenangan :

1. Untuk menerbitkan izin edar produk dan sertifikat sesuai dengan standar dan persyaratan keamanan, khasiat atau manfaat dan mutu serta pengujian obat dan makanan sesuai dengan ketentuan peraturan perundang-undangan;

2. Melakukan intelijen dan penyidikan di bidang pengawasan Obat dan Makanan sesuai dengan peraturan perundang-undangan;

3. Pemberian sanksi administratif sesuai dengan ketentuan peraturan perundangundangan.

Maka fungsi BPOM mencakup regulasi standarisasi, evaluasi produk sebelum diizinkan beredar, pemeriksaan dan penyidikan, pengawasan peredaran,

\footnotetext{
${ }^{11}$ Henny G. Rahayu, 'Peranan BPOM dan Tanggung Gugat Terhadap Obat-Obatan yang Melanggar Undang-Undang Perlindungan Konsumen’ (Skripsi, Fakultas Hukum Universitas Airlangga 2006).[21].

${ }_{12}$ Philipus M Hadjon, Pengantar Hukum Administrasi Indonesia (Gadjah Mada University Press 2002).[6].
} 
pengambilan contoh/sampling sekaligus melakukan pengujian laboraturium, informasi dan peringatan kepada publik di bidang penegakan hukum. Dengan fugsi ini, harapannya BPOM dapat melaksanakan kinerja dalam hal mengawasi obat dan makanan dapat dilakukan dengan baik. Sehingga akan lahir budaya hukum dan penegakan aturan hukum yang jelas untuk melindungi kepentingan konsumen maupun kepentingan pelaku usaha. ${ }^{13}$

Kewenangan tersebut yang mendasari BPOM untuk melakukan segala tindakan dibidang Obat dan Makanan, dan fungsi serta pengawasan menjadi tujuan utama BPOM dalam melindungi kepentingan konsumen. Disamping itu, di bidang perizinan dan standarisasi suatu produk juga perlu diperhatikan dan ditangani serius oleh BPOM. Standarisasi produk bertujuan untuk memberikan perlindungan kepada konsumen terhadap mutu suatu barang yang digunakan. Terus meningkatnya produksi barang yang dilakukan oleh pelaku usaha memungkinkan munculnya produk yang tidak memenuhi standar yang telah ditentukan oleh peraturan perundang-undangan. Wewenang BPOM juga mencakup pemberian sanksi. Sebagai lembaga pemerintah, BPOM memiliki wewenang khusus untuk memberikan sanksi kepada pelaku usaha yang terbukti tidak memenuhi peraturan mengenai obat dan makanan. Sanksi ini dapat berupa sanksi teguran, penyitaan, bahkan sanksi pidana. ${ }^{14}$

Adapun visi dan misi yang dipegang oleh BPOM adalah dalam hal keamanan obat dan makanan guna meningkatkan kesehatan masyarakat dan daya saing bangsa. Dan juga meningkatkan sistem pengawasan Obat dan Makanan berbasis risiko untuk melindungi masyarakat, mendorong kemandirian pelaku usaha dalam memberikan jaminan keamanan Obat dan Makanan serta memperkuat kemitraan dengan pemangku kepentingan, juga meningkatkan kapasitas kelembagaan. ${ }^{15}$ Sebagai lembaga pengawas, BPOM berkewajiban membina dan mendorong pelaku usaha agar dapat memberikan produk yang

\footnotetext{
${ }^{13}$ Rinayati, 'Tugas, Wewenang Dan Tanggung Jawab Badan Pengawas Obat Dan Makanan Dalam Rangka Perlindungan Konsumen' (Tesis, Pascasarjana Universitas Airlangga 2006).[23].

14 ibid.[31].

${ }^{15}$ Badan POM RI, "Visi dan Misi BPOM" (https://www.pom.go.id/new/view/direct/vision). Accessed on 14 Januari 2020.
} 
aman, berkhasiat/bermannfaat, dan bermutu dengan harapan agar pelaku usaha mempunyai kapasitas dan komitmen dalam memberikan jaminan atas keamanan, khasiat/manfaat, serta mutu Obat dan Makanan.

Apoteker maupun pemilik Apotek bertanggung gugat atas kerugian yang diderita oleh konsumen. Seperti hal nya apabila obat tersebut dikonsumsi oleh masyarakat lalu obat tersebut tidak mencantumkan label, komposisi, tanggal kadaluwarsa, sehingga dapat menyebabkan konsumen mengalami efek samping yang tidak diinginkan. Hal semacam ini dapat dijadikan sebagai pembuktian yang merupakan tanggung jawab seorang pelaku usaha sesuai dengan Pasal 28 UUPK, dan bentuk daripada tanggung gugat oleh pelaku usaha atas kerugian yang telah diderita oleh konsumen didasarkan pada Pasal 19 ayat (1) yang menentukan apabila pelaku usaha bertanggung jawab memberikan ganti rugi atas kerusakan, pencemaran, dan/atau kerugian konsumen akibat mengkonsumsi barang dan/atau jasa yang dihasilkan atau diperdagangkan. Dilanjutkan dengan Pasal 19 ayat (2) UUPK menjelaskan bahwa ganti rugi yang sebagaimana dimaksud pada ayat (1) dapat berupa pengembalian uang atau setara nilainya, atau perawatan kesehatan dan/atau pemberian santunan yang sesuai dengan ketentuan peraturan perundangundangan yang berlaku.

Undang-Undang Perlindungan Konsumen telah memberikasn kewenangan kepada BPSK selaku lembaga yang bertugas dalam menyelesaikan sengketa konsumen di luar pengadilan. Penyelesaian sengketa di luar pengadilan memang bukanlah jalan yang harus ditempuh konsumen sebelum pada akhirnya sengketa tersebut diselesaikan melalui lembaga peradilan. Penyelesaian sengketa di luar pengadilan dapat digunakan sebagai cara berdamai antara produsen dengan konsumen yang bersengketa. ${ }^{16}$ Selain itu, menurut Pasal 60 ayat (1) UUPK, dimana Badan Penyelesaian Sengketa Konsumen berwenang dalam menjatuhkan sanksi administrasi terhadap pelaku usaha yang melanggar ketentuan Pasal 19 ayat (2) dan ayat (3), Pasal 20, Pasal 25, dan juga Pasal 26.

\footnotetext{
${ }^{16}$ Indriyana D Mustikarini, 'Tanggung Gugat Produsen Obat Palsu Di Indonesia' (Skripsi, Fakultas Hukum Universitas Airlangga 2004).[52].
} 
Tanggung gugat obat racikan apotek tanpa resep dokter didasarkan pada Undang-Undang No. 8 Tahun 1999 berdasarkan kesalahan, hal ini tercermin dalam Pasal 28 UUPK. ${ }^{17}$ Sedangkan Pasal 27 UUPK, pelaku usaha dalam hal ini apoteker dan pemilik apotek sebagai produsen dibebaskan tanggung jawab atas kerugian yang diderita konsumen, jika:

1. Barang yang seharusnya atau dengan maksud tidak diedarkan;

2. Timbul cacat barang dikemudian hari;

3. Cacat barang yang ditimbulkan ditaatinya tentang kualifikasi barang;

4. Kelalaian yang disebabkan oleh konsumen;

5. Jangka waktu penuntutan lebih dari 4 tahun sejak barang dibeli atau jangka waktu yang telah diperjanjikan.

\section{Kesimpulan}

Apotek merupakan sarana pendistribusian obat dalam dunia kesehatan farmasi. Kedudukannya disebutkan pada Pasal 1 ayat 1 Permenkes Nomor 73 Tahun 2016 Tentang Standar Pelayanan Kefarmasian di Apotek. Terkait dengan peredaran obat, dan permenkes farmasi disebutkan obat dapat diserahkan berdasarkan: (a) Dengan resep dokter, (b) Tanpa resep dokter . Kemudian mengenai obat racikan, secara khusus disebutkan oleh permenkes PERMENKES Nomor 73 Tahun 2016 Tentang Standar Pelayanan Kefarmasian di Apotek merupakan bagian dari dispensing, dimana peracikan itu dilakukan apabila memang diperlukan, dan hanya dapat dilakukan berdasarkan pengkajian resep dokter. Sehingga ketika apoteker menyerahkan obat racikan kepada pasien dengan tanpa resep dokter, hal ini tergolong menjadi obat ilegal. Berdasakan klasifikasi dari Badan POM, obat ilegal sendiri merupakan obat yang tidak memiliki nomor izin edar (tidak terdaftar di Badan POM) sehingga tidak terjamin keamanan, mutu dan khasiatnya.

Badan Pengawas Obat dan Makanan (BPOM) merupakan lembaga yang diberikan kewenangan dalam mengawasi hingga menerbitkan izin dalam peredaran obat dan makanan. Secara khusus tugas dan kewenangan BPOM terdapat pada Peraturan Presiden Nomor 80 Tahun 2017 yaitu: menerbitkan izin edar produk

\footnotetext{
${ }^{17}$ ibid. [61].
} 
dan sertifikat sesuai standar dan persyaratan keamanan, melakukan intelijen dan penyidikan di bidang pengawasan obat dan makanan, pemberian sanksi administratif sesuai peraturan perundang-undangan. Dalam hal ini BPOM dapat melakukan sweeping terhadap obat-obat yang beredar apakah memiliki izin edar atau tidak. Penegakan yang dilakukan oleh BPOM dapat memberikan sanksi seperti penarikan obat, melakukan pemusnahan, dsb. Kemudian terhadap konsumen yang telah dirugikan, UUPK memberikan pilihan untuk menuntut haknya, yaitu melalui perdamaian, BPSK, maupun gugatan melalui pengadilan.

\section{Daftar Bacaan}

\section{Buku}

Barkatullah A, Hak-Hak Konsumen (Nusamedia 2010).

Firmansyah M, Tata Cara Mengurus Perizinan Usaha Farmasi \& Kesehatan (Visimedia 2009).

Hadjon P, Pengantar Hukum Administrasi Indonesia (Gadjah Mada University Press 2002).

Hartono S, Aspek-Aspek Hukum Perlindungan Konsumen Pada Era Perdagangan Bebas (Mandar Maju 2000).

HR Ridwan, Hukum Administrasi Negara (Rajawali Pers 2013).

Nasution Az, Hukum Perlindungan Konsumen Suatu Pengantar (Diadit Media 2001).

Sidabalok J, Hukum Perlindungan Konsumen di Indonesia (Citra Aditya Bakti 2006).

Sidarta, Hukum Perlindungan Konsumen Indonesia (Grafindo 2000).

Soekanto S, Aspek Hukum Apotek dan Apoteker (Mandar Maju 1990).

Sutedi A, Hukum Perizinan Dalam Sektor Pelayanan Publik (Sinar Grafika 2011).

Widjaja G dan Ahmad Yani, Hukum Tentang Perlindungan Konsumen (Gramedia Pustaka Utama 2000). 


\section{Karya Ilmiah}

Rahayu H, 'Peranan BPOM dan Tanggung Gugat Terhadap Obat-Obatan yang Melanggar Undang-Undang Perlindungan Konsumen' (Skripsi, Fakultas Hukum Universitas Airlangga 2006).

Rinayati, 'Tugas, Wewenang Dan Tanggung Jawab Badan Pengawas Obat Dan Makanan Dalam Rangka Perlindungan Konsumen' (Tesis, Pascasarjana Universitas Airlangga 2006).

Mustikarini I, 'Tanggung Gugat Produsen Obat Palsu Di Indonesia' (Skripsi, Hukum Universitas Airlangga 2004).

Subagyono B, 'Prinsip Mediasi Sengketa Konsumen Dalam Mediasi Terintegrasi di Pengadilan’ (Disertasi, Fakultas Hukum Universitas Airlangga 2019).

\section{Jurnal}

Abdulkadir S, "Model Kolaborasi Dokter, Apoteker, dan Direktur terhadap Peningkatan Efektivitas Teamwork di Rumah Sakit", (Jurnal Farmasi Klinik Indonesia 2017) 6(3). <http://jurnal.unpad.ac.id/ijcp/article/view/15572/ pdf $>$.

Allen V, 'The Art, Science, and Technology of Pharmaceutical Compounding: Fifth Edition', (International Journal of Pharmaceutical Compounding). $<\mathrm{https}$ :// www.pharmacist.com/sites/default/files/files/Allen_\%20Chap_\%201_ Art $\% 2 \mathrm{C} \% 20$ Science $\% 20$ and $\% 20$ Technology $\% 20$ of $\% 20$ Pharmaceutical $\% 20$ Compounding\%2C\%204e.pdf $>$.

Ariyulinda N, 'Urgensi Pembentukan Regulasi Penjualan Obat Melalui Media Online', (Jurnal Legislasi Indonesia 2018) 15(01). <http://e-jurnal.peraturan. go.id/index.php/jli/article/view/10/pdf>.

Bertawati, 'Profil Pelayanan Kefarmasian dan Kepuasan Konsumen Apotek di Kecamatan Adiwerna Kota Tegal', (Calyptra: Jurnal Ilmiah Mahasiswa Universitas Surabaya 2013) 2(2). <https://media.neliti.com/media/ publications/197617-profil-pelayanan-kefarmasian-dan-kepuasa.pdf $>$.

Rahmatini, "Agar Penulisan Resep Tetap Up To Date", (Majalah kedokteran Andalas 2009), 33(2). <http://jurnalmka.fk.unand.ac.id/index.php/art/article/ view/52/49>.

Syamsuni H, Ilmu Resep (EGC 2007).

Widyaswari R dan Chairun Wiedyaningsih, 'Evaluasi Profil Peresepan Obat 
Racikan Dan Ketersediaan Formula Obat Untuk Anak Di Puskesmas Propinsi DIY', (Majalah Farmasuetik 2012) 8(3). <https://jurnal.ugm.ac.id/ majalahfarmaseutik/article/view/24079/15756>.

Yuningsih R, 'Penguatan Kendali Pemerintah Terhadap Peredaran Obat dan Makanan', (Jurnal Aspirasi 2017) 8(1). <https://jurnal.dpr.go.id/index.php/ aspirasi/article/view/1252>.

Zuhaid M Alfan, Bambang Eko Turisno, dan R.Suharto, 'Perlindungan Konsumen Terhadap Peredaran Obat Tanpa Izin Edar yang Dijual Secara Online di Indonesia', (Diponegoro Law Journal 2016) 5(3). <https://www.neliti.com/ $\mathrm{id} /$ publications/19230/perlindungan-konsumen-terhadap-peredaran-obattanpa-izin-edar-yang-dijual-secara $>$.

\section{Laman}

Badan POM RI, "Visi dan Misi BPOM”, https:/www.pom.go.id/new/view/direct/ vision.

Satria B, “Apotek Dan Apoteker Menjual Obat Tanpa Resep Dokter, Bagaimana Hukumnya?” www.best-dokter.com 2017.

\section{Perundang-undangan}

Staatsblaad Nomor 23 Tahun 1847 tentang Burgerlijk Wetboek voor Indonesie (Kitab Undang-Undang Hukum Perdata).

Undang-Undang Nomor 8 Tahun 1999 tentang Perlindungan Konsumen (Lembaran Negara Tahun 1999 Nomor 42, Tambahan Lembaran Negara Nomor 3821).

Undang-Undang Nomor 36 Tahun 2009 tentang Kesehatan (Lembaran Negara Tahun 2009 Nomor 144, Tambahan Lembaran Negara Nomor 5063).

Peraturan Pemerintah Nomor 72 Tahun 1998 tentang Pengamanan Sediaan Farmasi dan Alat Kesehatan (Lembaran Negara Tahun 1998 Nomor 138, Tambahan Lembaran Negara Nomor 3781).

Peraturan Pemerintah Nomor 58 Tahun 2001 tentang Pembinaan dan Pengawasan Penyelenggaraan Perlindungan Konsumen (lembaran Negara Tahun 2001 Nomor 103, Tambahan Lembaran Negara Nomor 4126).

Peraturan Pemerintah Nomor 51 Tahun 2009 tentang Pekerjaan Kefarmasian (Lembaran Negara Tahun 2009 Nomor 124, Tambahan Lembaran Negara Nomor 5044). 
Peraturan Presiden Nomor 80 Tahun 2017 tentang Badan Pengawas Obat dan Makanan (Lembaran Negara Tahun 2017 Nomor 180).

Peraturan Menteri Kesehatan Nomor: 02396/A/SK/VIII/86 tentang Tanda khusus Obat Keras Daftar G, ditetapkan pada tanggal 7 Agustus 1986.

Peraturan Menteri Kesehatan Nomor: 917/MENKES/PER/X/1993 tentang Wajib Daftar Obat Jadi, ditetapkan pada tanggal 23 Oktober 1993.

Peraturan Menteri Kesehatan Nomor 73 Tahun 2016 tentang Standar Pelayanan Kefarmasian di Apotek (Berita Negara Tahun 2017 Nomor 50).

Peraturan Menteri Kesehatan Nomor 9 Tahun 2017 tentang Apotek (Berita Negara Tahun 2017 Nomor 276).

Peraturan Kepala Badan Pengawas Obat dan Makanan Republik Indonesia Nomor HK.04.1.33.12.11.09938 Tahun 2011 tentang Kriteria dan Tata Cara Penarikan Obat yang Tidak Memenuhi Standar dan/atau Persyaratan (Berita Negara Tahun 2011 Nomor 551). 